\title{
EFEK PERBEDAAN JENIS PAKAN DAN HABITAT TERHADAP NILAI FEMALE MATURITY INDEX (FMI) PADA PENELURAN KEPITING BAKAU (Scylla serrata)
}

\section{EFFECTS OF DIFFERENT TYPE OF FEED AND HABITAT ON FEMALE MATURITY INDEX (FMI) VALUE DURING SPAWNING-PHASE Scylla serrata}

\author{
Muhammad Zulhafid ${ }^{1}$, G. Nugroho Susanto ${ }^{1}$, Sri Murwani ${ }^{1}$ \\ 1 Jurusan Biologi FMIPA Universitas Lampung \\ e-mail : gnugroho@unila.ac.id \\ Jurusan Biologi FMIPA Universitas Lampung \\ Jl. Prof.Dr. Soemantri Brojonegoro No. 1, Bandar Lampung, Lampung, Indonesia, 35145
}

\begin{abstract}
Abstrak
Kepiting bakau (Scylla serrata) adalah salah satu jenis komoditas perikanan yang potensial untuk dikembangkan, karena memiliki nilai gizi yang tinggi. Permintaan masyarakat terhadap jenis kepiting bakau ini cukup besar, sehingga menyebabkan penangkapan besar-besaran terhadap stok di alam. Salah satu usaha budidaya yang dirasa cukup potensial untuk mengatasi dampak tersebut adalah dengan cara produksi peneluran kepiting bakau matang gonad yang pemeliharaannya lebih mudah dan singkat. Tujuan penelitian ini adalah untuk mengetahui perkembangan nilai Female Maturity Index (FMI) selama tahap peneluran dan untuk mengetahui pengaruh pemberian jenis pakan dan habitat yang berbeda terhadap nilai Female Maturity Index. Kepiting bakau betina yang belum berisi telur diberi perlakuan berupa perbedaan habitat pemiliharaan yaitu kawasan aliran pasang surut dan kawasan mangrove serta diberi tiga jenis pakan yang berbeda yaitu ikan rucah, cumi-cumi, dan kerang. Hasil penelitian menunjukkan bahwa pemberian pakan dan habitat yang berbeda tidak memberikan efek yang nyata terhadap perkembangan nilai FMI. Pemberian pakan cumi-cumi dan pemeliharaan di habitat mangrove berpengaruh nyata $(\alpha=0,05)$ terhadap pertambahan lebar segmen abdomen ke 5 , abdomen terbesar dan berat tubuh kepiting bakau pada masa peneluran. Pemberian jenis pakan dan habitat yang berbeda tidak menyebabkan pertambahan panjang dan lebar karapas kepiting bakau.
\end{abstract}

Kata kunci : kepiting bakau, nilai FMI, habitat, jenis pakan

\begin{abstract}
Scylla serrata is a fisheries commodity that has high nutritious contains. The high demand of society on this commodity highly increased and the production mainly relies on the existing population in nature, thus result in decreasing population of Scylla serrata in nature. To overcome the problem is Scylla serrata cultivation on spawning phase. The purposes of the research are to determine the development of the Female Mature Index (FMI) during spawning phase and to determine the effects of various type of feed and habitat on Female Mature Index (FMI). The adult female Scylla serrata pre-pregnant was feed with various combination treatments in the form of different habitats; tidal flow area and mangrove area as well as three different types of feed; fishes, squid and mussels. The result shows that three types of feed and habitats did not give significant effects $(\alpha=5 \%)$ on the development of the value of Female Mature Index (FMI). In addition, The combination treatment of squid feed and mangrove habitat gives highest value on the increasing of fifth abdominal segment width, abdomen width and body weight during spawning period. However all combination treatments in this research did not influence significantly on the increasing of body length and carapace width.
\end{abstract}

Key word : Scylla serrata, value of FMI, habitat,

\section{PENDAHULUAN}

Kepiting bakau (Scylla serrata) merupakan salah satu komoditas perikanan pada perairan pantai, khususnya di daerah mangrove. Kepiting bakau telah dikenal di pasar dalam dan luar negeri kare- na rasanya yang lezat dan bernilai gizi tinggi yakni mengandung berbagai nutrien penting (Catacutan, 2002). Daging kepiting bakau mengandung $47.5 \%$ protein, $11.20 \%$ lemak dan nutrisi penting bagi sumber makanan dan kesehatan seperti vitamin B12, fosfor, seng, tembaga, dan se- 
lenium. Daging kepiting bakau mengandung kolesterol yang cukup tinggi, namun rendah kandungan lemak jenuh (Karim, 2005).

Budidaya kepiting bakau dapat dilakukan dengan cara pembesaran, penggemukan, dan peneluran. Proses peneluran kepiting bakau terjadi di dalam tubuh induk betina setelah pembuahan. Telur yang akan dibuahi kemudian dimasukkan pada tempat penyimpanan sperma. Setelah dibuahi, telur tersebut ditempatkan pada bagian bawah abdomen dan hingga menetas (Prianto, 2007).

Banyak kendala dan faktor yang mempengaruhi proses peneluran kepiting bakau di alam. Kerusakan habitat berdampak langsung terhadap ketersediaan pakan dan kawasan perlindungan. Beberapa faktor yang mempengaruhi produksi peneluran kepiting bakau antara lain salinitas, kadar oksigen terlarut, $\mathrm{pH}$, suhu dan faktor alam lainnya. Salah satu metode yang digunakan untuk mengetahui tingkat kematangan gonad pada produksi peneluran kepiting bakau adalah melalui pengamatan terhadap nilai Female Maturity Index (FMI), yaitu dengan cara mengukur dan membandingkan penambahan lebar bagian abdomen pada kepiting betina yang sedang bertelur (Poovachiranon, 1991).

Selama periode perkembangan gonad kepiting bakau membutuhkan lebih banyak asupan protein (asam amino), lemak, karbohidrat, vitamin, dan mineral guna memenuhi kebutuhan energi dalam proses metabolisme serta proses perkembangan gonad. Menurut Giri, dkk., (2002) setidaknya dibutuhkan pakan yang mengandung $52 \%$ protein guna memaksimalkan proses pematangan gonad.

\section{BAHAN dan METODE}

Penelitian ini dilakukan dari bulan Mei sampai dengan September 2012, di Dusun Perumpung, Desa Sidodadi, Kecamatan Padang Cermin, Kabupaten Pesawaran dan laboratorium Zoologi Jurusan Biologi FMIPA Universitas Lampung.

Metode yang digunakan dalam penelitian adalah metode eksperimen dengan Rancangan Acak Kelompok (RAK) Faktorial dengan 9 ekor sampel sebagai ulangan. Perlakuan berupa pemeliharaan pada dua habitat yang berbeda yaitu habitat aliran pasang surut dan habitat mangrove, serta dilakukan pemberian tiga jenis pakan yang berbeda yaitu ikan rucah, cumi-cumi, dan kerang.

Parameter yang digunakan dalam penelitian ini adalah parameter biologi dan parameter kualitas air. Parameter biologi yang diukur meliputi panjang dan lebar karapas, segmen abdomen terbesar dan segmen abdomen ke lima, serta berat tubuh dari kepiting bakau. Sementara parameter penunjang yang diukur bersamaan dengan pelaksanaan sampling yakni setiap 7-8 hari sekali meliputi Salinitas, Suhu, dan $\mathrm{pH}$.

Sebagai tempat pemeliharaan digunakan 2 buah kurungan bambu berbentuk persegi panjang dengan ukuran $2 \times 1,30 \times 1 \mathrm{~m}$, yang masing-masing memiliki 3 ruang didalamnya dan ukurannya disesuaikan dengan jumlah induk yang akan ditebar (Efrizal, dkk., 2001). Indukan kepiting bakau yang diperoleh berasal dari hasil tangkapan di alam, dimana kepiting yang digunakan berjenis kelamin betina dengan kondisi telur kosong atau belum terisi penuh telur dengan bobot tubuh berkisar 150-250 gram.

Sebanyak 9 ekor kepiting dipelihara dalam setiap kurungan. Sebelum dipelihara dalam kurungan, terlebih dahulu dilakukan pengukuran panjang dan lebar karapas serta abdomennya, dan berat tubuh. Sebagai penanda, setiap individu sampel diberi ikatan menggunakan tali rafia pada bagian capitnya.

Frekuensi pemberian pakan dilakukan sebanyak 2 kali, saat pagi hari yaitu pada pukul tujuh pagi dan sore hari pada pukul lima. Pakan yang diberikan adalah ikan rucah, cumi-cumi, dan kerang dengan jumlah $5 \%$ dari berat tubuh total. Setiap 7-8 hari dilakukan pengukuran berat tubuh, lebar dan panjang karapaks, ruas abdomen terbesar dan abdomen ke-5 dari seluruh indukan kepiting yang berjumlah 54 ekor.

\section{HASIL dan PEMBAHASAN}

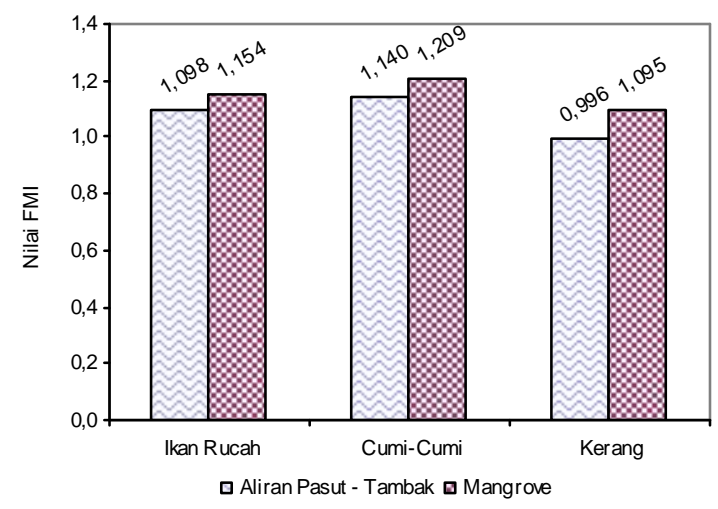

Gambar 1. Nilai FMI kepiting bakau.

Rerata nilai FMI tertinggi (Gambar 1) terdapat pada sampel kepiting yang dipelihara pada habitat mangrove dengan pakan cumi-cumi yaitu se- 
besar 1.209, sedangkan pada habitat tambak pasang surut dengan pakan yang sama diperoleh nilai sebesar 1.140. Pada habitat mangrove dengan pakan ikan rucah diperoleh FMI sebesar 1.154, dan pada habitat tambak pasang surut dengan pakan yang sama nilai FMlnya sebesar 1.098. Peningkatan nilai FMI terendah terdapat pada habitat tambak pasang surut dengan pakan kerang yaitu 0.996, sedangkan pada habitat mangrove dengan pakan yang sama sebesar 1.095.

Efek perbedaan habitat pemeliharaan serta pemberian tiga jenis pakan yang berbeda guna merangsang kematangan gonad, tidak berbeda nyata terhadap peningkatan nilai Female Maturity Index (FMI). Hal ini diduga karena pengaruh faktor eksternal dari setiap individu kepiting bakau itu sendiri. Menurut Effendi (1978) ada faktor eksternal yang mencakup, ukuran tubuh, umur, kematangan reproduksi, keturunan, parasit dan penyakit yang dapat mempengaruhi tingkat reproduksi kepiting.

Tinggi rendahnya pertambahan nilai FMI pada setiap perlakuan mungkin disebabkan oleh perbedaan asupan makanan yang diterima serta kondisi habitat tempat pemeliharaan. Prianto (2007) menyatakan bahwa secara fisiologis kepiting membutuhkan energi dalam pakan yang dipergunakan untuk adaptasi, pemeliharaan atau pengganti sel atau jaringan yang rusak, aktivitas metabolisme, reproduksi serta untuk mempercepat kematangan gonad.

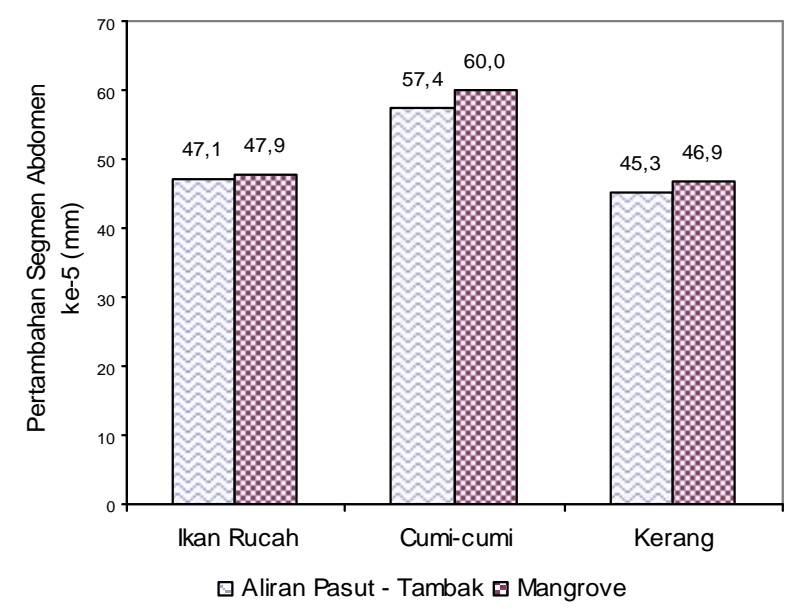

Gambar 2. Rerata pertambahan lebar segmen abdomen ke 5 per minggu dari induk kepiting bakau yang diberi pakan dan habitat pemeliharaan berbeda.

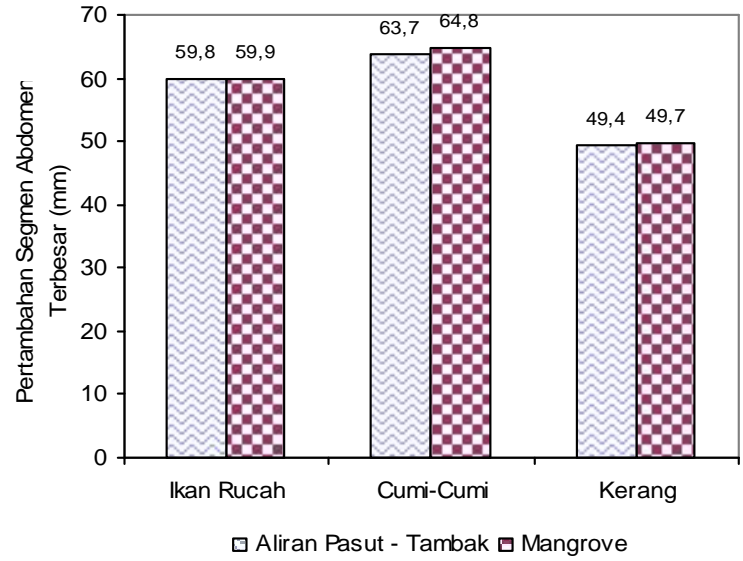

Gambar 3. Rerata pertambahan lebar segmen abdomen terbesar per minggu dari induk kepiting bakau yang diberi pakan dan habitat pemeliharaan berbeda.

Pemberian pakan cumi-cumi pada habitat mangrove memberikan efek yang nyata $(\alpha=0,05)$ pada pertambahan segmen abdomen ke-5 dan segmen abdomen terbesar kepiting bakau pada masa peneluran dibandingkan dengan pemberian pakan ikan rucah dan kerang pada habitat mangrove dan tambak pasang surut (Gambar 2 dan 3). Kondisi ini diduga disebabkan oleh nilai gizi cumicumi terutama kandungan protein yang mencapai $67 \%$ dengan kalori mencapai 1,5-2,5 gram (Suharsono, 1988 dan Astawan, 2009), dibandingkan dengan kandungan protein ikan rucah dan kerang (Nurjanah et.al. 2005 dan Novian, 2008).

Menurut Akiyama et.al. (1991) dan Djuwito et.al. (1992), protein dari jenis pakan yang diformulasikan untuk meningkatkan partumbuhan dan reproduksi kepiting bakau harus mengandung 10 asam amino esensial, terutama lisin, arginin, leusin, isoleusin, dan valin. Kandungan asam amino dalam pakan segar yang berasal dari hewan dan tumbuhan baik digunakan sebagai pakan kepiting bakau (Jauncey dan Ross, 1982) karena asam amino ini tidak bisa disintesis oleh kepiting bakau dan harus tersedia di dalam pakan (Kanazawa, 1982).

Hasil analisis ragam menunjukkan bahwa efek pemberian tiga jenis pakan dan habitat berbeda nyata pada taraf $(\alpha=0,05)$ terhadap rerata pertambahan berat tubuh dari kepiting bakau pada masa peneluran (Gambar 4). Perbedaan pertambahan berat tubuh kepiting bakau yang paling tinggi pada pemberian pakan cumi-cumi dengan pemeliharaan pada habitat mangrove. Hasil ini sesuai dengan penelitian Djuwito et.al. (1992) bahwa cumi-cumi memberikan hasil lebih baik dari pada jenis pakan yang lain untuk penggemukan dan peneluran kepiting bakau. Hal ini 
diduga oleh kandungan protein dalam cumi-cumi yang cu-kup tinggi yaitu $71,5 \%$ (BombeoTuburan et.al. 1999). Tingginya protein yang terkandung dalam cumi-cumi mempercepat pertambahan berat tubuh dan proses kematangan reproduksinya (Kuntiyo, 1994; Cholik, 2005).

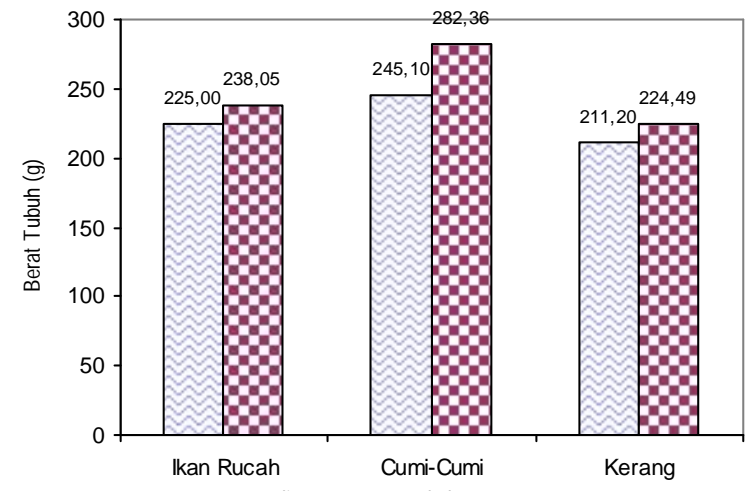

$\square$ Aliran Pasut - Tambak $\square$ Mangrove

Gambar 4. Rerata pertambahan berat tubuh per minggu dari induk kepiting bakau yang diberi pakan dan habitat pemeliharaan berbeda

Kondisi ini ditunjang oleh habitat mangrove yang sesuai untuk pertumbuhan kepiting bakau. Menurut Motoh (1979) habitat mangrove merupakan habitat alami bagi kepiting bakau. Selain itu pengendalian terhadap kualitas habitat juga dirasa cukup berpengaruh untuk merangsang pertumbuhan dan perkembangaan kematangan gonad dan kelangsungan hidup kepiting bakau, khususnya pada periode peneluran (O'Connor, 2007).

Pertambahan panjang dan lebar karapas kepiting bakau yang dipelihara dikedua habitat dengan diberi tiga jenis pakan yang berbeda sangat sedikit (Gambar 5 dan 6). Hal ini diduga karena asupan makanan yang dite-rima kepiting bakau tidak lagi untuk pertumbuhan karapas melainkan untuk memicu kecepatan pematangan gonad. Menurut Effendi (1978) selama periode peneluran, sebagian dari asupan makanan akan digunakan untuk memicu kematangan gonad, tidak ada pertumbuhan morfologi seperti pertambahan panjang dan lebar karapas karena tidak lagi terjadi proses moulting pada kepiting bakau di masa peneluran.

Hal ini diperkuat oleh pernyataan Locwood (1967) bahwa hewan dari golongan crustaceae dapat melakukan proses moulting yang berpengaruh pada pertambahan panjang dan lebar bagian tubuhnya. Begitu pula pada kepiting bakau, panjang dan lebar karapasnya baru akan meningkat setelah melakukan proses moulting. Menurut Arriola (1940), selama tidak terjadi proses moulting, maka tidak ada pertambahan panjang dan lebar dari karapas kepiting selama masa peneluran, hanya terlihat peningkatan kecembungan pada bagian punggung karapas, yang disebabkan peningkatan ukuran dari setiap pertambahan tingkat kematangan gonad kepiting bakau tersebut.

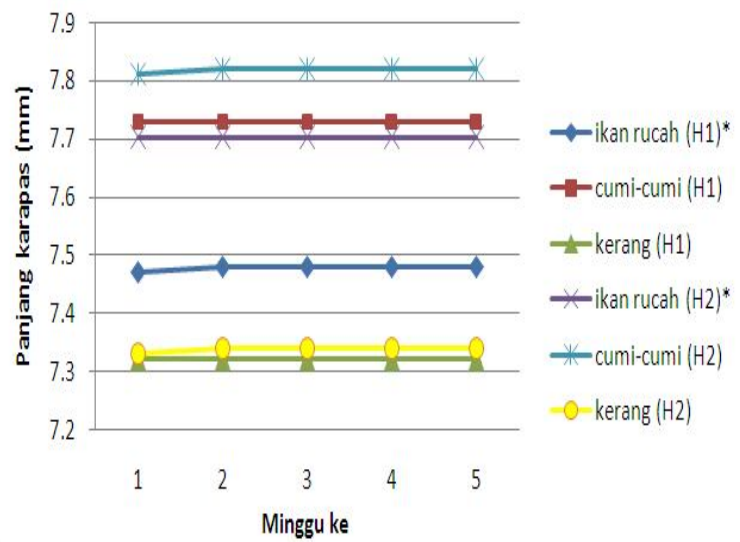

Gambar 5. Rerata pertambahan panjang karapas per minggu dari induk kepiting bakau yang diberi pakan dan habitat pemeliharaan berbeda

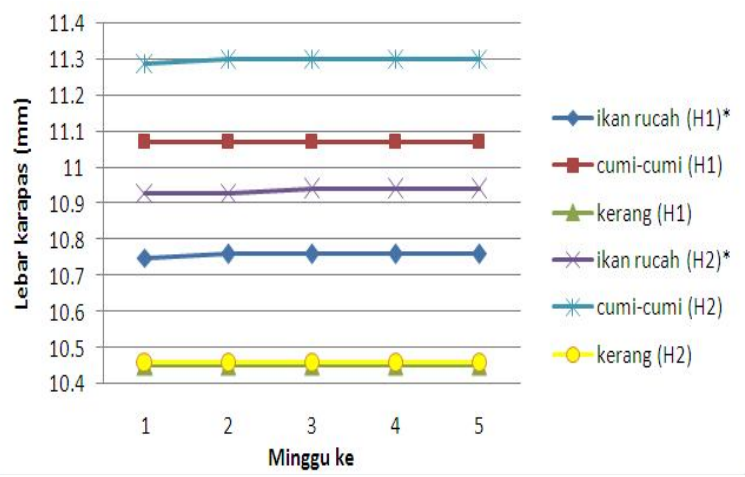

Gambar 6. Rerata pertambahan lebar karapas per minggu dari induk kepiting bakau yang diberi pakan dan habitat pemeliharaan berbeda. $\mathrm{H} 1$ ) habitat tambak pasang surut dan $\mathrm{H} 2$ ) habitat mangrove.

\section{KESIMPULAN}

Pemberian pakan dan habitat yang berbeda tidak memberikan efek yang nyata terhadap perkembangan nilai FMI kepiting bakau. Pemberian pakan cumi-cumi dan pemeliharaan di habitat mangrove berpengaruh nyata $(\alpha=5 \%)$ terhadap pertambahan lebar segmen abdomen ke-5, abdomen terbesar dan berat tubuh kepiting bakau pada masa peneluran. Pemberian jenis pakan dan habitat yang berbeda tidak menyebabkan pertambahan panjang dan lebar karapas kepiting bakau. 


\section{DAFTAR PUSTAKA}

Akiyama, D.M., Dominy, W.G. and Lawrence, A.L. 1991.Penaeid shrimp nutrition for the commercial feed industry: Revised. Proceedings Aquaculture Feed Processing and Nut Workshop. Singapore, American Soy Bean Association.

Astawan, 2009. Pengaruh Efek Pemberian Pakan Terhadap Pertumbuhan dan Kelangsungan Hidup Kepiting Bakau (Scylla serrata Forskal) Di Laguna Gasang Gadang. Jurnal Penelitian Mangrove dan Pesisir.

Arriola, F. J. 1940. A Primary Study Of The Life History Of Scylla serrata Forskal. Philip. J. Sci : 437-456

Bombeo-Tuburan, I. E.B. Coniza., E.M. Rodrigues and R.F. Agbayani. 1999. Culture and Economic of Wild Grouper (Epinephelus coioides) using three type of feed in pond. Aquaculture. 131 (2): 229-240.

Catacutan, M. R., 2002. Growth and Body Composition of Juvenile Mud Crab,

Scylla serrata, Fed Different Dietary Protein and Lipid Levels and Protein to Energy Ratio. Aquaculture 208: 113-123.

Cholik, F. 2005. Review of Mud Crab Culture Research in Indonesia. Central

Research Institute for Fisheries 310 CRA: Jakarta

Djuwito, S.R., Hartoko, A. and Sulardiono, B. 1992. Technology development of mud crab culture for hatchery and grow-out ponds. Fisheries Department, Faculty of Animal Husbandry, Diponegoro University

Effendi. 1978. Biologi Perikanan. Fakultas perikanan IPB. Bogor.

Efrizal, Nurman, dan Novriansyah. 2001. Luas ruang gerak yang berbeda terhadap pertumbuhan dan kelangsungan hidup kepiting bakau (Scylla serrata) pada keramba bambu system sekat. Jurnal Penelitian Mangrove dan Pesisir 5(1): 13-21.

Giri, N. A., Yunus, K. Suwirya \& M. Marzuki. 2002. Kebutuhan protein untuk pertumbuhan Juvenil kepiting bakau Scylla serrata. J.Penel. Perik, Indonesia. 8(5): 31-36.

Jauncey, K. and Ross, B. 1982. Tilapia Feed and Feeding. Institute of Aquaculture, University of Stirling, Scotland, UK.

Kanazawa, A. 1982. Penaeid nutrition. In: Pruder, G.D., Langdon, C.J. and Conklin, D.E. ed. Proceedings of the Second International Conference on Aquaculture Nutrition: Biochemical and Physiological Approaches to Shellfish Nutrition, Baton Rouge, LA, Louisiana State University, 87-105.
Kanna, A.2002. Budidaya Kepiting Bakau : Pembenihan dan Pembesaran. Kanisius. Jakarta.

Karim, M. Y., 2005. Kinerja Pertumbuhan Kepiting Bakau Betina (Scylla serrata Forsskal) pada Berbagai Salinitas Media dan Evaluasinya pada Salinitas Optimum dengan Kadar Protein Pakan Berbeda. Disertasi, Institut Pertanian Bogor, Bogor.

Kuntiyo, A. Zaenal dan T. Supratno. 1994. Budidaya Kepiting Bakau (Scylla serrata) di tambak dengan sistem Progesy. Dalam laporan tahunan Balai Budidaya Air Payau 1994-1995. Direktorat Jenderal Perikanan. Departemen Pertanian, Jakarta.

Locwood, A. P. M. 1967. Aspect of The Fisiology of Crustacea. W. H. Freeman And Comp. San Fansisco

Motoh, H. 1979. Edible Crustaceans In The Philipinnes, 11th. In $A$ Series Asian Aquaculture. 2 (10): 5.

Novian. 2008. Karakteristik miofibril Kering Ikan Kuniran (Upeneus sp.) Diekstrak Menggunakan Enzim Papain dengan Metode Press Panas. September. 2008. 10 Januari 2011.

O'connor. 2007. Aspects of the general biology and fishery of the mud crab Scylla serrata (Forskål) in Moreton Bay. Ph.D. Thesis, University of Queensland

Poovachiranon, S. 1991. Biological Studies of The Mud Crab Scylla serrata (Forskal) Of The Mangrove Ecosystem In The Andaman Sea. Report of the Mud Crab Culture and Trade Held at Swat, Thailand.

Prianto, E. 2007. Peran Kepiting Sebagai Spesies Kunci (Keystone Spesies) pada Ekosistem Mangrove. Prosiding Forum Perairan Umum Indonesia IV. Balai Riset Perikanan Perairan Umum Banyuasin.

Suharsono, 1988. Pengaruh Efek Pemberian Pakan Terhadap Pertumbuhan dan Kelangsungan Hidup Kepiting Bakau (Scylla serrata Forskal) Di Laguna Gasang Gadang. Jurnal Penelitian Mangrove dan Pesisir. 